\title{
MONITORAMENTO DA INTRUSÃO SALINA NO AQUÍFERO INGLESES - FLORIANÓPOLIS, SC
}

\author{
Lauro César Zanatta ${ }^{1}$; Larissa Ramage²,
}

\begin{abstract}
Resumo
O presente artigo demonstra a importância do monitoramento da cunha salina para preservação do Aquífero Costeiro dos Ingleses, localizado na Praia dos Ingleses, Florianópolis, SC. A exploração excessiva de aquíferos costeiros, em desequilíbrio com o processo de recarga, coloca o sistema sob risco de salinização por intrusão marinha. O fenômeno provoca a degradação do aquífero, tornando suas águas impróprias para diversos usos, incluindo o consumo humano. A Costa Norte da Ilha de Santa Catarina tem na água subterrânea sua principal fonte de abastecimento. A região é composta por um aquífero do tipo granular e a geologia local é constituída basicamente por depósitos quaternários arenosos com intercalações de níveis argilosos que ocupam a faixa litorânea, sobrepostos a um embasamento cristalino de profundidade variável. O presente estudo utiliza dados de 2014 até os dias atuais, realizado através do monitoramento de 27 poços e 5 piezômetros localizados próximo à praia. Os laudos das análises físico-químicas foram realizados no laboratório da Companhia Catarinense de Águas e Saneamento - CASAN. Os estudos geofísicos realizados com resistivímetro com a utilização de Sondagem Elétrica Vertical (SEV) e Caminhamento Elétrico (CE) confirmaram que o Aquífero dos Ingleses se encontra bem preservado, não apresentando intrusão por avanço de cunha salina.
\end{abstract}

\begin{abstract}
This article is to demonstrate the importance of monitoring the salt wedge to preserve the Coastal Aquifer Ingleses, located in Praia dos Ingleses, Florianópolis, SC. The overexploitation of coastal aquifers in disequilibrium with the recharge process, puts the system at risk of salinization by seawater intrusion. The phenomenon causes a degradation of the aquifer, making their water unsuitable for many uses, including human consumption. The North Coast of the island of Santa Catarina has groundwater their main source of supply. The region is composed of a granular aquifer

${ }^{1}$ Geólogo - Companhia Catarinense de Águas e Saneamento. Rua 15 de novembro, 230. Balneário Estreito, Florianópolis - SC. (48) 32215841 lzanatta@casan.com.br

${ }^{2}$ Geóloga - - Companhia Catarinense de Águas e Saneamento. Rua 15 de novembro, 230. Balneário Estreito, Florianópolis - SC. (48) 3221 58 42 lramage@casan.com.br
\end{abstract}


type and local geology consists mainly of Quaternary sandy deposits with interbedded clayey levels occupying the coastal strip, overlying a crystalline basement of variable depth. This study uses 2014 data to the present day, performed by monitoring 27 wells and 5 piezometers located near the beach. The reports of physical and chemical analyzes were performed in the laboratory of Catarinense Company for Water and Sanitation - CASAN. Geophysical studies of resistivity with the use of vertical electrical sounding (VES) and resistivity, confirmed that the Ingleses Aquifer is well preserved.

Palavras - chave - Salinização, Monitoramento, Aquífero Costeiro.

\section{1 - INTRODUÇÃO}

Na Costa Norte da Ilha de Santa Catarina a água subterrânea é a principal alternativa para o abastecimento público sendo fundamental para o desenvolvimento do turismo do Estado, para uma população de 115.000 habitantes. O abastecimento de água no Norte da Ilha é realizado através da exploração de um conjunto de 27 poços, linearmente distribuídos, que captam água do Aquífero Costeiro Ingleses sendo denominado Sistema Costa Norte, O aquífero apresenta uma vulnerabilidade alta por ter seu nível piezométrico bem próximo a superfície. Outra grande preocupação é a contaminação do aquífero com o avanço da cunha salina. São realizadas análise físico - químicas periodicamente nos poços de monitoramento instalados ao longo das praias, perfurados estrategicamente próximo a Praia dos Ingleses, Praia do Santinho e Praia do Moçambique. Os principais parâmetros de controle utilizados para o monitoramento são os índices de cloreto e condutividade elétrica realizados tanto nos poços de monitoramento como nos poços para abastecimento público em operação no Sistema.

Anualmente é realizada a manutenção preventiva dos poços visando à máxima capacidade de vazão para atendimento do abastecimento de água principalmente na temporada de verão. Durante o verão todos os poços entram em operação aumentando consideravelmente o volume de captação do aquífero.

O sistema de monitoramento tem a função de acusar a abrangência de uma determinada fonte de poluição/contaminação na qualidade da água subterrânea, no caso inspecionar o avanço da cunha salina em direção ao aquífero. As amostras são coletadas nos poços de monitoramento distribuídos estrategicamente próximo a linha da praia, oferecendo subsídios para o diagnóstico da situação. A localização estratégica e a construção de poços de monitoramento, aliadas aos métodos eficientes de coleta, acondicionamento e análise de amostras, permitirá resultados bastante coerentes sobre o controle da contaminação do aquífero com o aumento do teor de cloreto em direção ao aquífero 
costeiro. $\mathrm{O}$ excesso de bombeamento dos poços é a principal causa da salinização dos aquíferos costeiros.

\section{2 - CARACTERIZAÇÃO DA ÁREA}

\section{1 - Hidrogeologia}

O Norte da Ilha é compreendido por uma planície de origem marinha desenvolvida paralelamente ao relevo cristalino, com orientação norte-sul (Figura 1). O Aqüífero Ingleses abrange a praia homônima e as porções interiores do sistema deposicional costeiro. $\mathrm{O}$ sistema aquífero é predominantemente livre, composto por areias finas a médias, com intercalação descontinua de níveis areno-argilosos sobreposto a uma camada de argila que funciona como horizonte confinante. Sob o ponto de vista hidrogeológico, as dunas presentes na área de estudo funcionam como um elemento de recarga, favorecendo as condições de extração.

Os poços do Aquífero Ingleses apresentam profundidades que variam de 47 a $77 \mathrm{~m}$. Quantos aos parâmetros físico-químicos analisados, o pH médio encontrado é 4,4, o conteúdo de cloreto médio é $28,45 \mathrm{mg} / \mathrm{L}$, a condutividade elétrica média de 76,05 $\mu \mathrm{S} / \mathrm{cm}$.

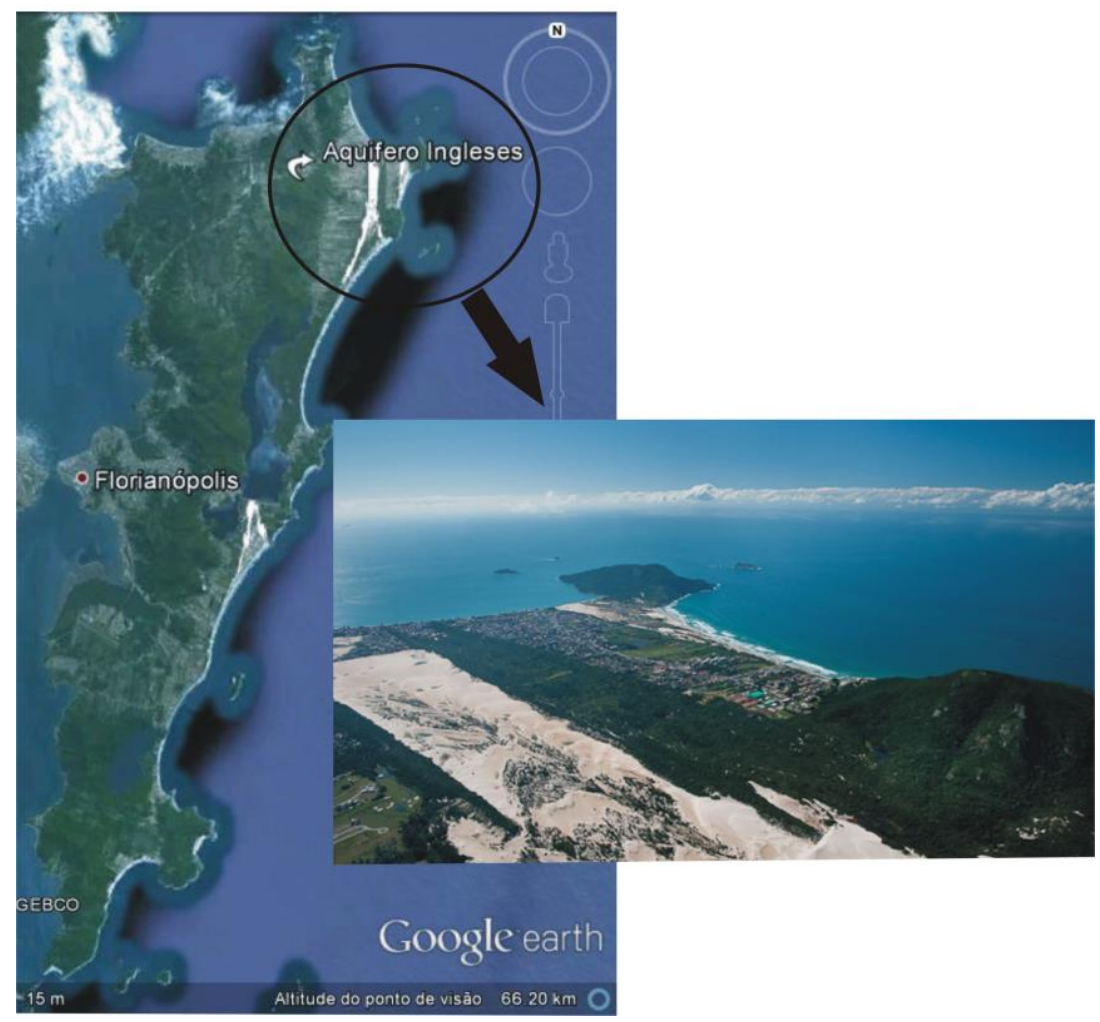

Figura 1 - Localização da área, Norte da Ilha de Santa Catarina, Aquífero Ingleses.

\section{3 - MONITORAMENTO}


Mensalmente é realizada a coleta d'água nos piezômetros existente pela equipe de manutenção da CASAN para análise do índice de cloreto e condutividade elétrica para verificar se há indícios do avanço da cunha salina (Figura 2). Nos períodos da temporada de verão (dezembro a março) as amostragens são realizadas semanalmente.

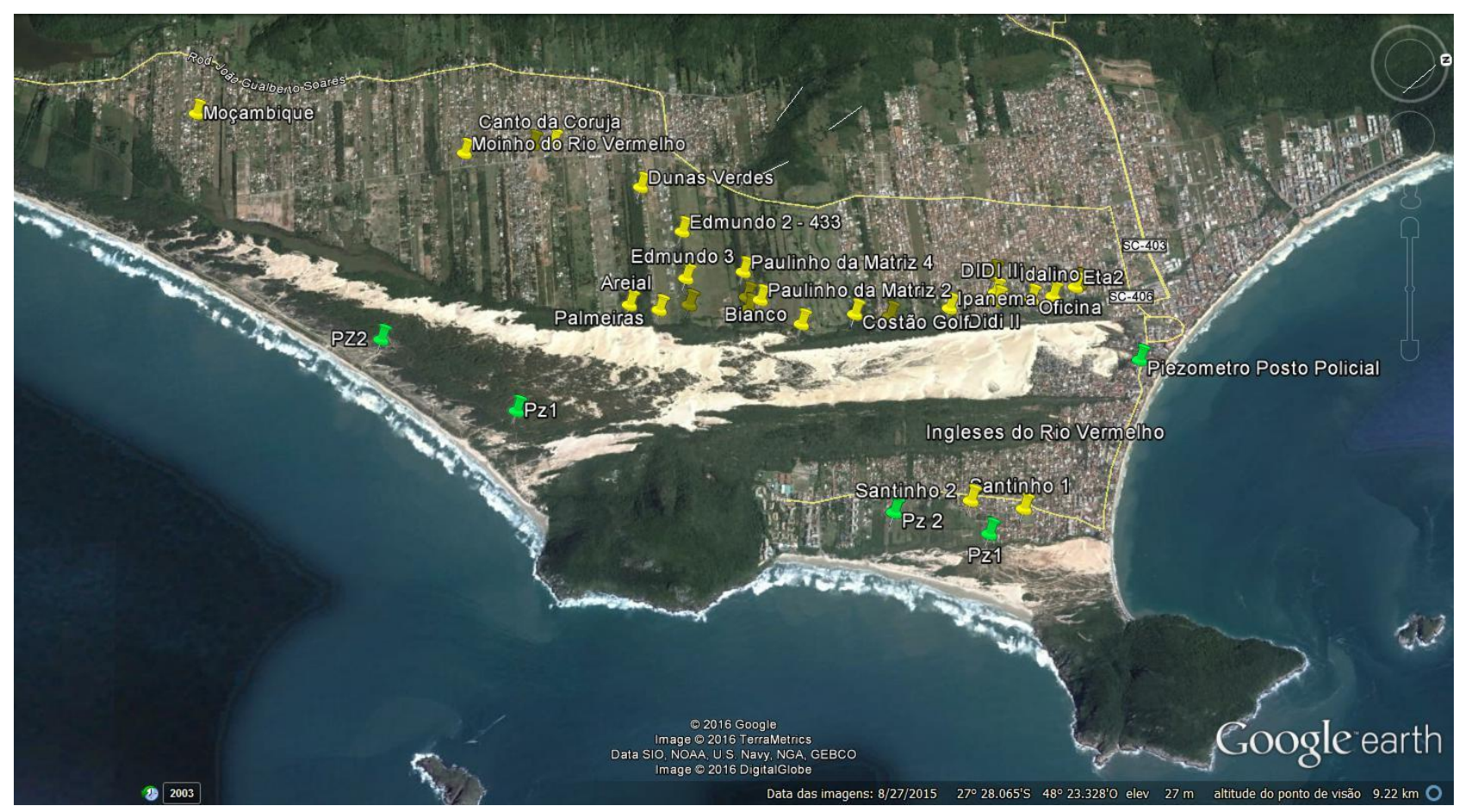

Figura 2 - Localização dos poços e piezômetros/poços de monitoramento nas Praias dos Ingleses,

Santinho e Moçambique - norte da ilha, Florianópolis, SC. Em amarelo poços utilizados para abastecimento público, em verde poços de monitoramento empregados para o controle do nível do avanço da cunha salina.

\section{4 - METODOLOGIA}

A água parada pode não ser representativa da qualidade da água do aquífero. Portanto o técnico responsável pela coleta deve remover a água estagnada no poço e no pré-filtro, de tal forma que a água da Formação substitua a água estagnada. Para a renovação da água no piezômetro é utilizado um "Kit de bombeamento" (Figura 3). O procedimento de esgotamento deve assegurar que toda a água estagnada seja renovada. A operação deve permitir o rebaixamento do nível de água acima do topo do filtro para assegurar que a água se mova ascendentemente no mesmo. 


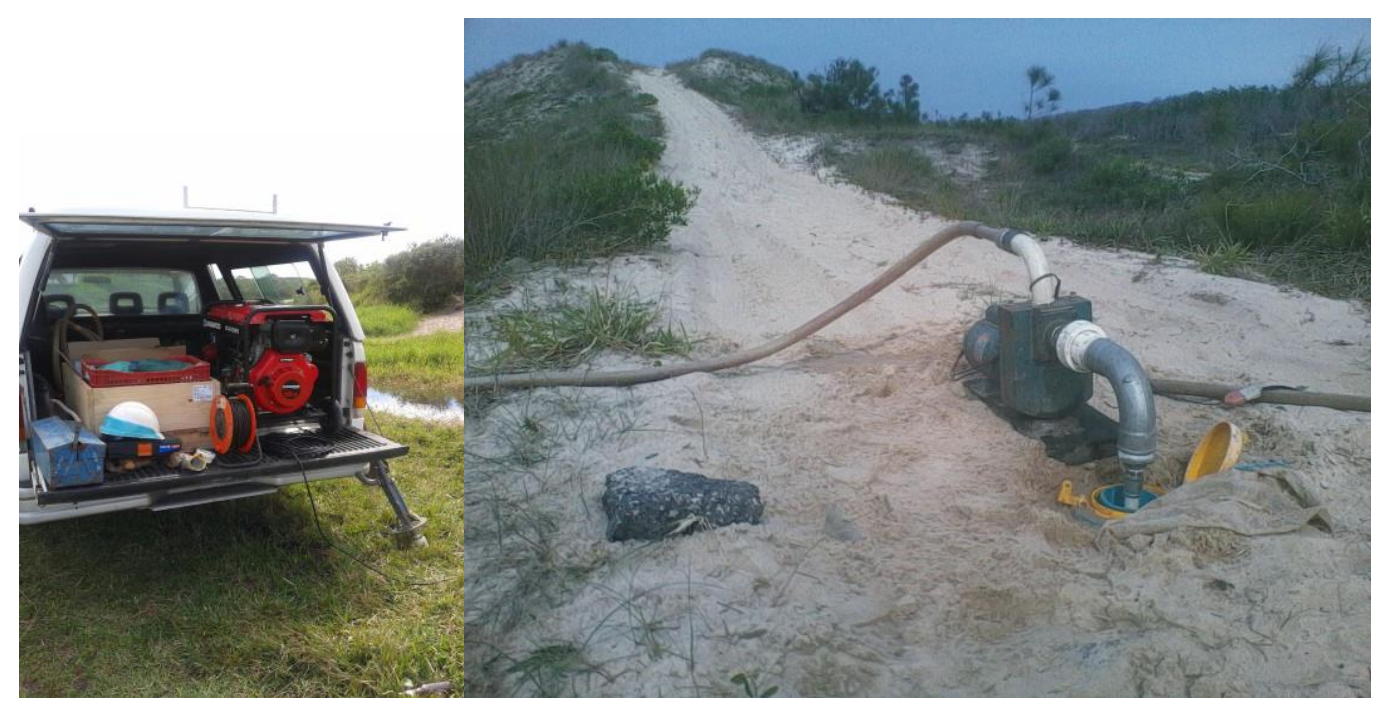

Figura 3 - Veículo equipado com Kit de bombeamento da equipe técnica responsável pela coleta das amostras nos piezômetros e poços.

Foram realizadas análises para avaliar a evolução dos índices de cloreto e condutividade elétrica de 2014 até dias atuais. As análises foram realizadas no Laboratório da CASAN e o método analítico utilizado foi o Standard Methods (APHA -AWWA-WEF, 1995).

Além do monitoramento periódico mensal das análises das amostras d'água nos piezômetros foi realizado um estudo geofísico com o uso de Resistivímetro. Consiste, basicamente, de uma fonte controlada para emissão de corrente elétrica e medidores para a corrente e a diferença de potencial gerada. A potência da fonte utilizada foi de 200 Watts. Foram utilizadas duas técnicas para aplicação do método, uma destinada a exploração horizontal/lateral, o Caminhamento Elétrico - CE e outra, destinada a investigação vertical, a Sondagem Elétrica Vertical - SEV.

\section{5 - RESULTADOS}

\subsection{Análise Físico - Química.}

\subsubsection{Cloretos}

Os índices de cloreto podem ser considerados muito importantes no controle da salinização dos aquíferos costeiros, o valor máximo permitido para o consumo humano conforme a Portaria do Ministério da Saúde 2914/2011 é de 250 mg/L.

Foram realizadas coletas nos 5 piezômetros e nos 2 poços da Praia do Santinho. O Piezômetro Posto Policial encontra-se a $150 \mathrm{~m}$ da linha de praia nos Ingleses (Tab. 1, Fig. 4). Os piezômetros: Santinho I está $360 \mathrm{~m}$ e o Santinho II está $330 \mathrm{~m}$ da linha de praia do Santinho (Tab 2 e 3, Fig. 5 e 6). Os piezômetros $\mathrm{Pz} 1$ e Pz 2 na Praia do Moçambique distam respectivamente 350 e $170 \mathrm{~m}$ respectivamente da linha de praia (Fig. 8 e 9, Tab.4 e Tab. 5). 
Tabela 1 - Valores de Cloreto e Condutividade Elétrica (CE) - Piezômetro Posto Policial.

\begin{tabular}{cccc}
$\begin{array}{c}\text { Amostra } \\
\text { No }\end{array}$ & Data & $\begin{array}{c}\text { Cloretos } \\
\mathrm{mg} \mathrm{Cl} / \mathrm{L}\end{array}$ & $\begin{array}{c}\text { CE } \\
\text { us/cm }\end{array}$ \\
1 & $17 / 01 / 2014$ & 21,90 & 112,50 \\
2 & $22 / 01 / 2014$ & 37,10 & 114,50 \\
3 & $24 / 01 / 2014$ & 14,30 & 101,90 \\
4 & $28 / 01 / 2014$ & 36,02 & 121,50 \\
5 & $30 / 01 / 2014$ & 36,80 & 129,70 \\
6 & $29 / 10 / 2014$ & 34,73 & 159,00 \\
7 & $29 / 12 / 2014$ & 44,67 & 178,20 \\
\hline \hline 8 & $12 / 01 / 2015$ & 41,44 & 121,50 \\
9 & $20 / 01 / 2015$ & 42,21 & 138,10 \\
10 & $02 / 02 / 2015$ & 41,55 & 185,50 \\
11 & $09 / 02 / 2015$ & 44,04 & 214,00 \\
12 & $18 / 02 / 2015$ & 41,40 & 191,70 \\
13 & $23 / 02 / 2015$ & 41,25 & 130,20 \\
14 & $23 / 03 / 2015$ & 41,15 & \\
15 & $25 / 05 / 2015$ & 24,30 & 123,10 \\
16 & $02 / 07 / 2015$ & 34,50 & 125,50 \\
17 & $21 / 07 / 2015$ & 39,70 & 165,80 \\
18 & $03 / 09 / 2015$ & 28,00 & 119,50 \\
19 & $08 / 10 / 2015$ & 39,94 & 175,50 \\
20 & $01 / 12 / 2015$ & 27,23 & 56,60 \\
\hline \hline 21 & $08 / 01 / 2016$ & 44,70 & 68,20 \\
22 & $18 / 01 / 2016$ & 42,68 & 79,10 \\
23 & $27 / 01 / 2016$ & 46,75 & 85,00 \\
24 & $02 / 02 / 2016$ & 47,50 & 84,20 \\
25 & $10 / 02 / 2016$ & 57,22 & 74,50 \\
26 & $17 / 02 / 2016$ & 44,58 & 94,30 \\
27 & $01 / 03 / 2016$ & 24,40 & 92,00 \\
28 & $22 / 03 / 2016$ & 46,47 & 560,00 \\
29 & $25 / 04 / 2016$ & 39,19 & 68,70
\end{tabular}

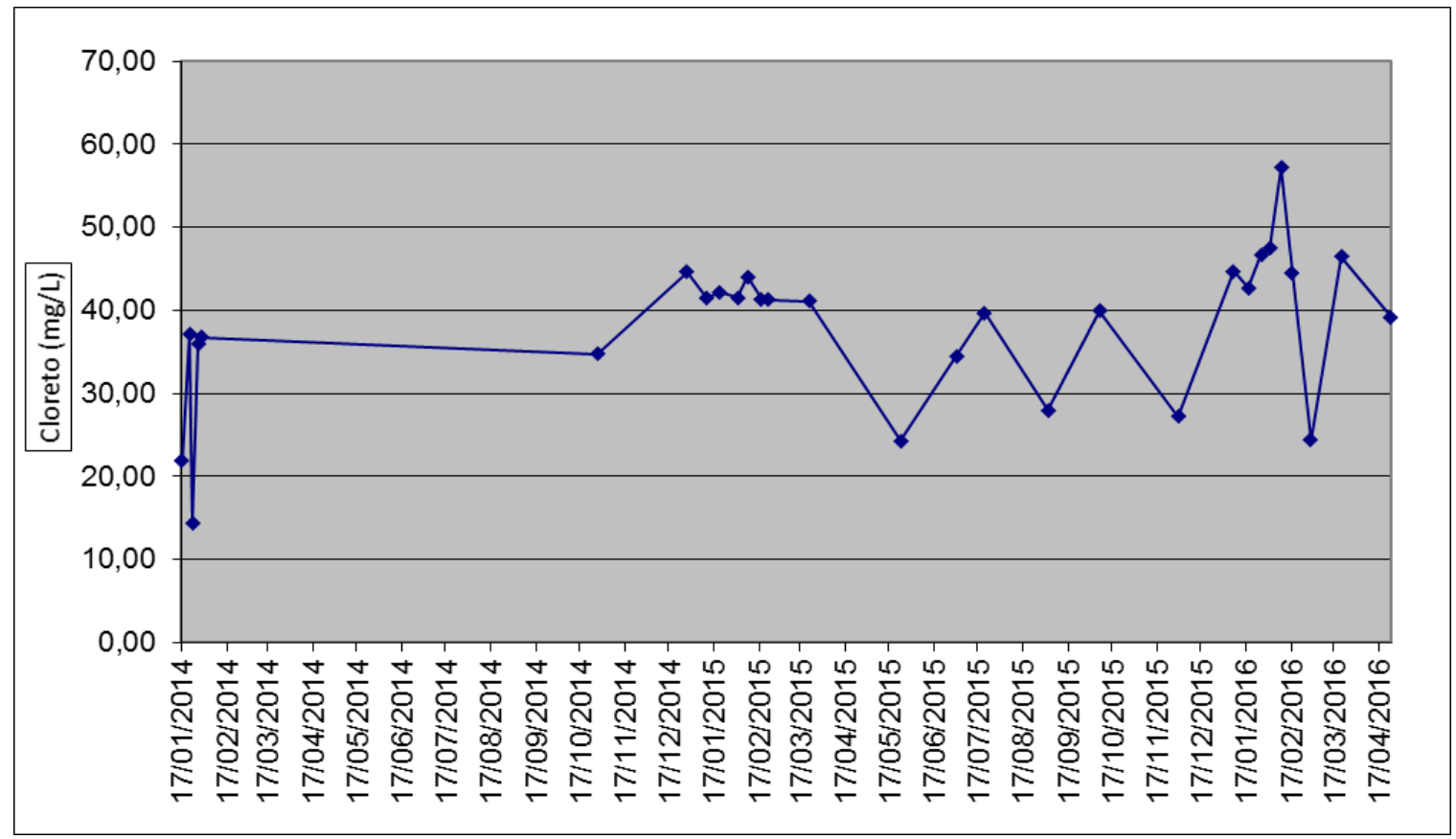

Figura 4 - Conteúdo de cloreto (mg/L) no Piezômetro Posto Policial. 
Tabela 2 - Valores de Cloreto e Condutividade Elétrica (CE) - Piezômetro Santinho I

\begin{tabular}{|c|c|c|c|}
\hline $\begin{array}{c}\text { Amostra } \\
\text { No }\end{array}$ & Data & $\begin{array}{c}\text { CE } \\
u s / c m\end{array}$ & $\begin{array}{c}\text { Cloretos } \\
\mathrm{mg} \mathrm{Cl} / \mathrm{L}\end{array}$ \\
\hline 1 & $01 / 12 / 2014$ & 241,00 & 43,08 \\
\hline 2 & $12 / 01 / 2015$ & 115,6 & 29,71 \\
\hline 3 & 20/01/2015 & 126,1 & 31,55 \\
\hline 4 & 02/02/2015 & 179,5 & 31,00 \\
\hline 5 & 09/02/2015 & 227,0 & 33,77 \\
\hline 6 & $18 / 02 / 2015$ & 236,0 & 36,60 \\
\hline 7 & 23/02/2015 & 146,9 & 37,97 \\
\hline 8 & 23/03/2015 & 195,0 & 31,22 \\
\hline 9 & $22 / 04 / 2015$ & 136,2 & 34,25 \\
\hline 10 & $25 / 05 / 2015$ & 202,0 & 28,30 \\
\hline 11 & 02/07/2015 & 147,5 & 27,80 \\
\hline 12 & 21/07/2015 & 169,1 & 27,91 \\
\hline 13 & 03/09/2015 & 158,2 & 26,20 \\
\hline 14 & 08/10/2015 & 164,0 & 29,64 \\
\hline 15 & $01 / 12 / 2015$ & 83,2 & 32,02 \\
\hline 16 & 07/01/2016 & & 30,99 \\
\hline 17 & $18 / 01 / 2016$ & & 27,84 \\
\hline 18 & $27 / 01 / 2016$ & 68,0 & 27,82 \\
\hline 19 & 02/02/2016 & 77,2 & 46,04 \\
\hline 20 & $10 / 02 / 2016$ & 59,1 & 27,86 \\
\hline 21 & $17 / 02 / 2016$ & 75,8 & 25,50 \\
\hline 22 & 01/03/2016 & 72,2 & 26,45 \\
\hline 23 & 22/03/2016 & 348,0 & 55,58 \\
\hline 24 & $24 / 04 / 2016$ & 73,9 & 33,06 \\
\hline
\end{tabular}

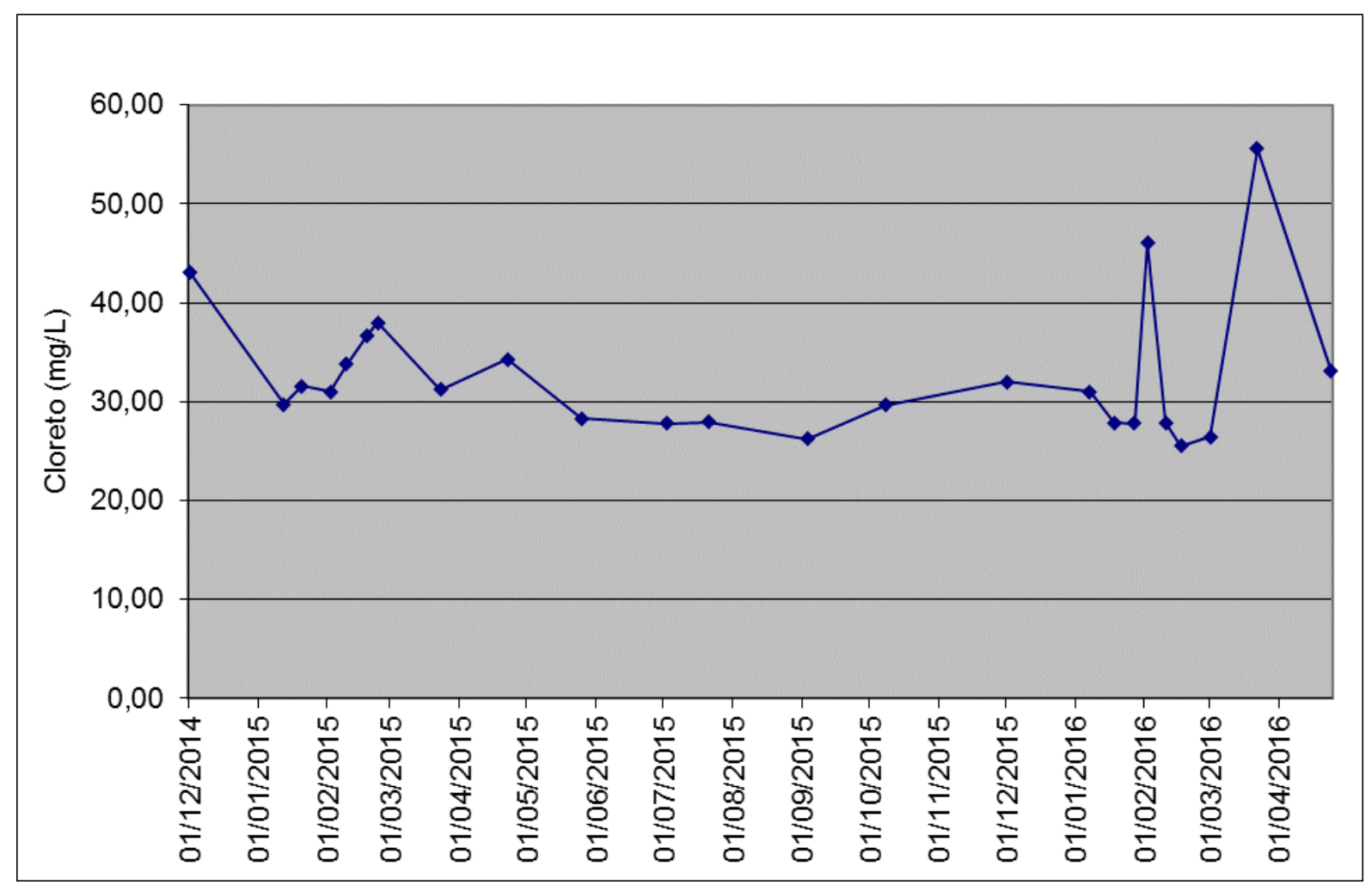

Figura 5 - Conteúdo de cloreto em mg/L no Piezômetro Santinho I. 
Tabela 3 - Valores de Cloreto e Condutividade Elétrica (CE) - Piezômetro Santinho II

\begin{tabular}{cccc}
$\begin{array}{c}\text { Amostra } \\
\text { No }\end{array}$ & Data & $\begin{array}{c}\text { CE } \\
\text { us/cm }\end{array}$ & $\begin{array}{c}\text { Cloretos } \\
\mathrm{mg} \mathrm{Cl} / \mathrm{L}\end{array}$ \\
\hline 1 & $30 / 12 / 2014$ & 204,00 & 30,05 \\
\hline \hline 2 & $12 / 01 / 2015$ & 62,2 & 15,77 \\
3 & $20 / 01 / 2015$ & 139,1 & 32,46 \\
4 & $26 / 01 / 2015$ & 64,4 & 15,0 \\
5 & $02 / 02 / 2015$ & 64,7 & 14,9 \\
6 & $09 / 02 / 2015$ & 261,0 & 28,67 \\
7 & $18 / 02 / 2015$ & 214,0 & 36,6 \\
8 & $23 / 03 / 2015$ & 135,6 & 24,5 \\
9 & $22 / 04 / 2015$ & 50,0 & 19,20 \\
10 & $25 / 05 / 2015$ & 72,0 & 13,70 \\
11 & $02 / 07 / 2015$ & 58,9 & 18,10 \\
12 & $20 / 07 / 2015$ & 71,5 & 14,17 \\
13 & $03 / 09 / 2015$ & 63,4 & 15,30 \\
14 & $08 / 10 / 2015$ & 84,1 & 22,46 \\
15 & $02 / 12 / 2015$ & 34,2 & 14,46 \\
\hline \hline 16 & $07 / 01 / 2016$ & & 16,62 \\
17 & $18 / 01 / 2016$ & 34,8 & 17,58 \\
18 & $27 / 01 / 2016$ & 29,9 & 16,53 \\
19 & $02 / 02 / 2016$ & 31,3 & 17,47 \\
20 & $10 / 02 / 2016$ & 28,3 & 15,11 \\
21 & $01 / 03 / 2016$ & 31,3 & 16,06 \\
22 & $22 / 03 / 2016$ & 150,7 & 19,36 \\
23 & $25 / 04 / 2016$ & 88,7 & 24,56
\end{tabular}

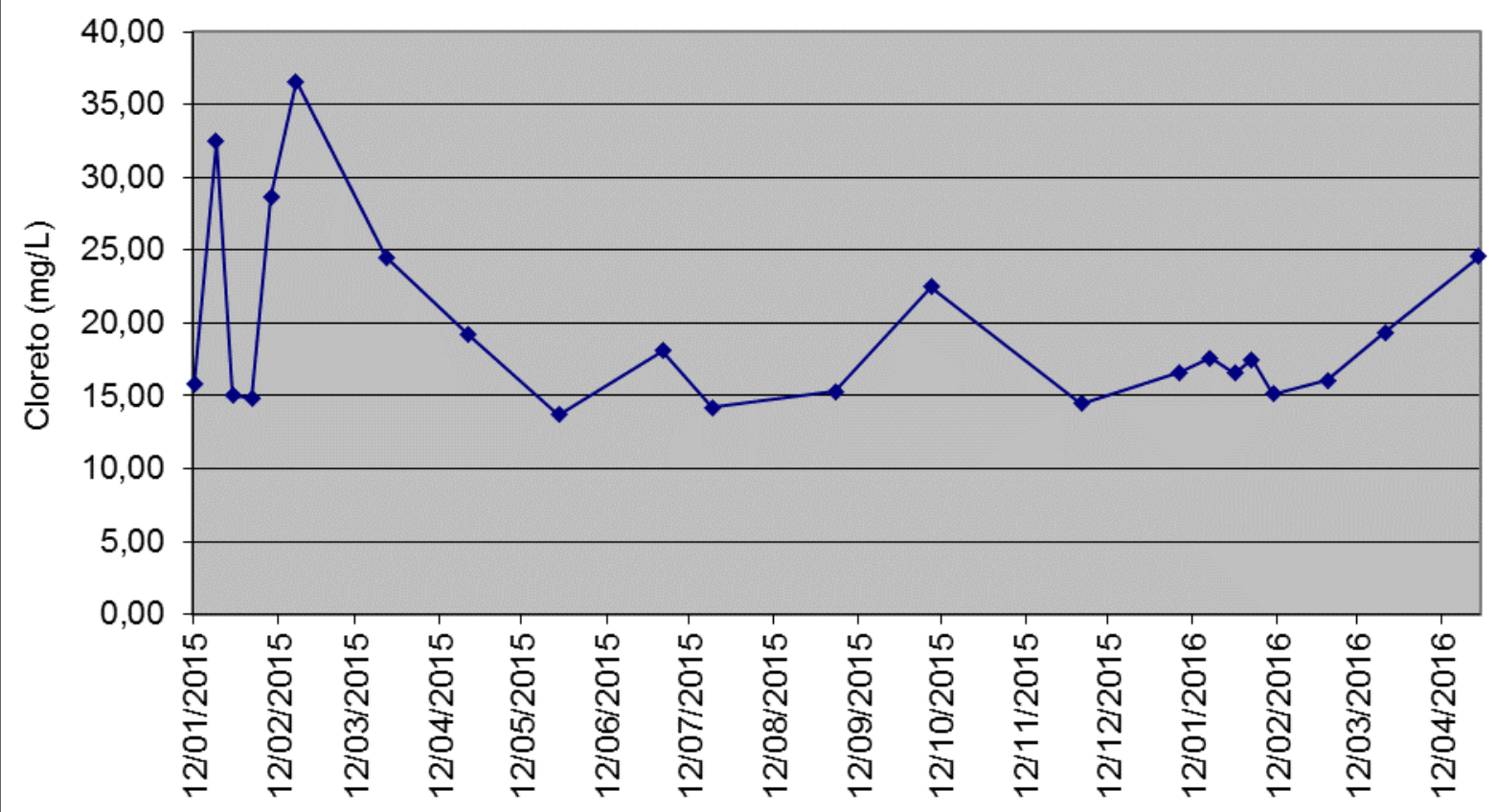

Figura 6 - Conteúdo de cloreto em mg/L no Piezômetro Santinho II. 


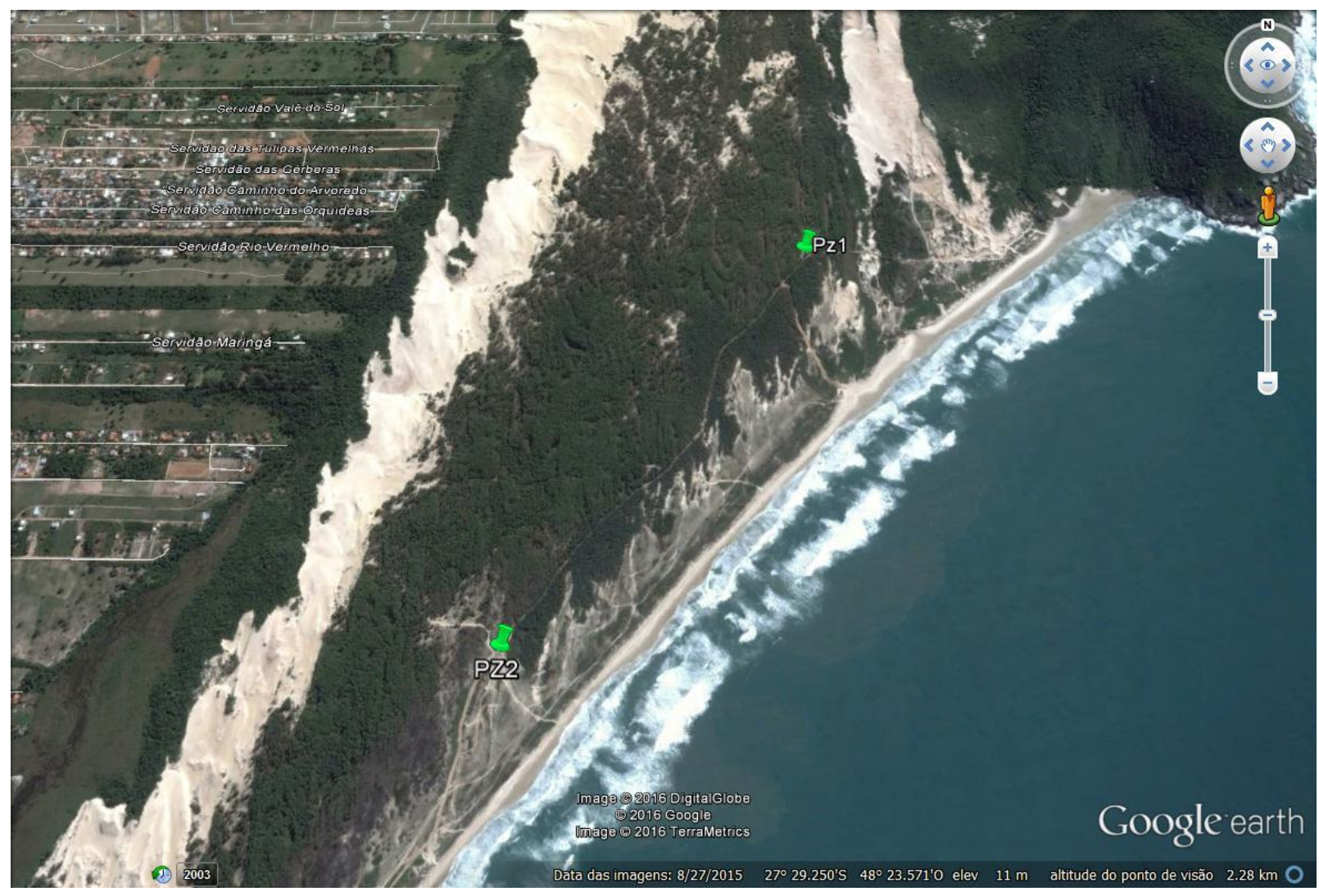

Figura 7 - Imagem do Google ${ }^{\mathrm{R}}$ mostrando a localização dos piezômetros PZ 1 e PZ 2 na Praia do Moçambique, Florianópolis, SC.

Tabela 4 - Valores de Cloreto e Condutividade Elétrica (CE) - Piezômetro Moçambique 1.

\begin{tabular}{cccc}
$\begin{array}{c}\text { Amostra } \\
\text { No }\end{array}$ & Data & $\begin{array}{c}\text { CE } \\
\text { Us/cm }\end{array}$ & $\begin{array}{c}\text { Cloretos } \\
\mathrm{mg} \mathrm{Cl} / \mathrm{L}\end{array}$ \\
1 & $01 / 12 / 2014$ & 82,30 & 16,88 \\
\hline \hline 2 & $20 / 01 / 2015$ & 68,8 & 18,10 \\
3 & $27 / 01 / 2015$ & 84,6 & \\
4 & $03 / 02 / 2015$ & 80,9 & 18,10 \\
5 & $10 / 02 / 2015$ & 90,1 & 35,18 \\
6 & $20 / 02 / 2015$ & 85,4 & 19,38 \\
7 & $23 / 03 / 2015$ & 422,0 & 20,11 \\
8 & $26 / 05 / 2015$ & 79,6 & 17,23 \\
9 & $01 / 07 / 2015$ & 77,5 & 20,10 \\
10 & $20 / 07 / 2015$ & 96,0 & 17,77 \\
11 & $02 / 09 / 2015$ & 107,1 & 20,16 \\
12 & $08 / 10 / 2015$ & 96,1 & 19,83 \\
13 & $01 / 12 / 2015$ & 115,3 & 24,51 \\
\hline \hline 14 & $08 / 01 / 2016$ & 38,7 & 24,18 \\
15 & $20 / 01 / 2016$ & 39,9 & 20,75 \\
16 & $05 / 02 / 2016$ & 36,7 & 20,78 \\
17 & $08 / 02 / 2016$ & 41,5 & 19,83 \\
18 & $12 / 02 / 2016$ & 41,2 & 21,77 \\
19 & $18 / 02 / 2016$ & 41,5 & 19,93 \\
20 & $24 / 02 / 2016$ & 41,2 & 21,65 \\
21 & $15 / 03 / 2016$ & 37,7 & 24,46 \\
22 & $29 / 04 / 2016$ & 39,7 & 21,25
\end{tabular}




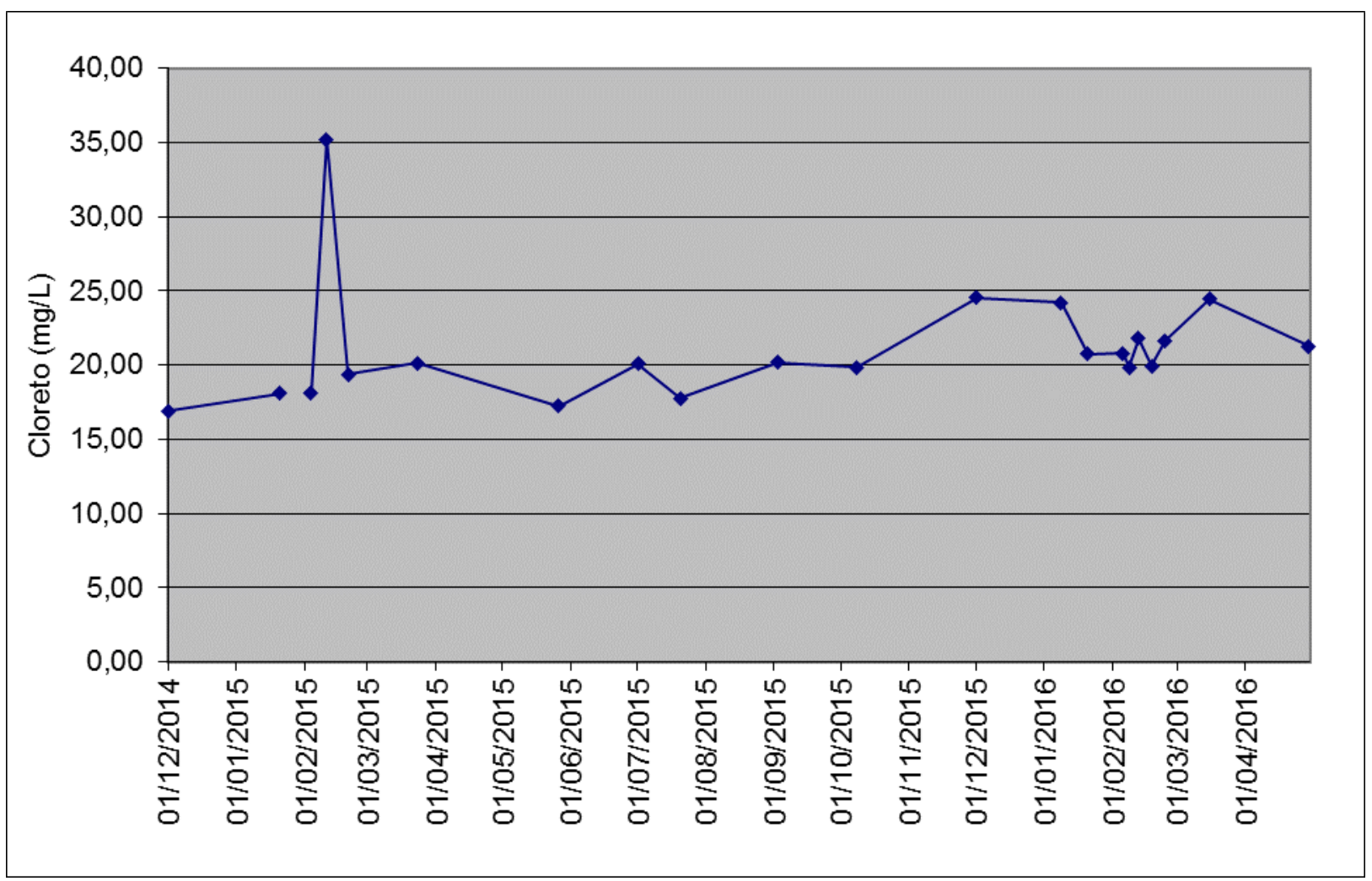

Figura 8 - Conteúdo de cloreto no Piezômetro Moçambique 1.

Tabela 5 - Valores de Cloreto e Condutividade Elétrica (CE) - Piezômetro Moçambique 2.

\begin{tabular}{cccc}
$\begin{array}{c}\text { Amostra } \\
\text { No }\end{array}$ & Data & $\begin{array}{c}\text { CE } \\
\text { Us/cm }\end{array}$ & $\begin{array}{c}\text { Cloretos } \\
\mathrm{mg} \mathrm{Cl} / \mathrm{L}\end{array}$ \\
1 & $01 / 12 / 2014$ & 153,50 & 38,11 \\
\hline \hline 2 & $20 / 01 / 2015$ & 100,4 & 26,05 \\
3 & $27 / 01 / 2015$ & 138,9 & 42,30 \\
4 & $03 / 02 / 2015$ & 146,3 & 34,60 \\
5 & $10 / 02 / 2015$ & 188,0 & 37,04 \\
6 & $20 / 02 / 2015$ & 145,7 & 38,1 \\
7 & $23 / 03 / 2015$ & 204,0 & 33,2 \\
8 & $26 / 05 / 2015$ & 117,2 & 31,03 \\
9 & $01 / 07 / 2015$ & 141,0 & 37,70 \\
10 & $20 / 07 / 2015$ & 145,7 & 29,70 \\
11 & $02 / 09 / 2015$ & 154,8 & 33,67 \\
12 & $08 / 10 / 2015$ & 160,0 & 38,89 \\
13 & $01 / 12 / 2015$ & 152,4 & 30,58 \\
\hline \hline 14 & $08 / 01 / 2016$ & 56,5 & 28,08 \\
15 & $19 / 01 / 2016$ & 57,1 & 27,2 \\
16 & $05 / 02 / 2016$ & & 25,5 \\
17 & $08 / 02 / 2016$ & 63,5 & 25,5 \\
18 & $12 / 02 / 2016$ & 53,0 & 24,3 \\
19 & $18 / 02 / 2016$ & 63,5 & 25,5 \\
20 & $24 / 02 / 2016$ & 67,1 & 26,7 \\
21 & $15 / 03 / 2016$ & 61,7 & 31,17 \\
22 & $29 / 04 / 2016$ & 45,6 & 21,7
\end{tabular}




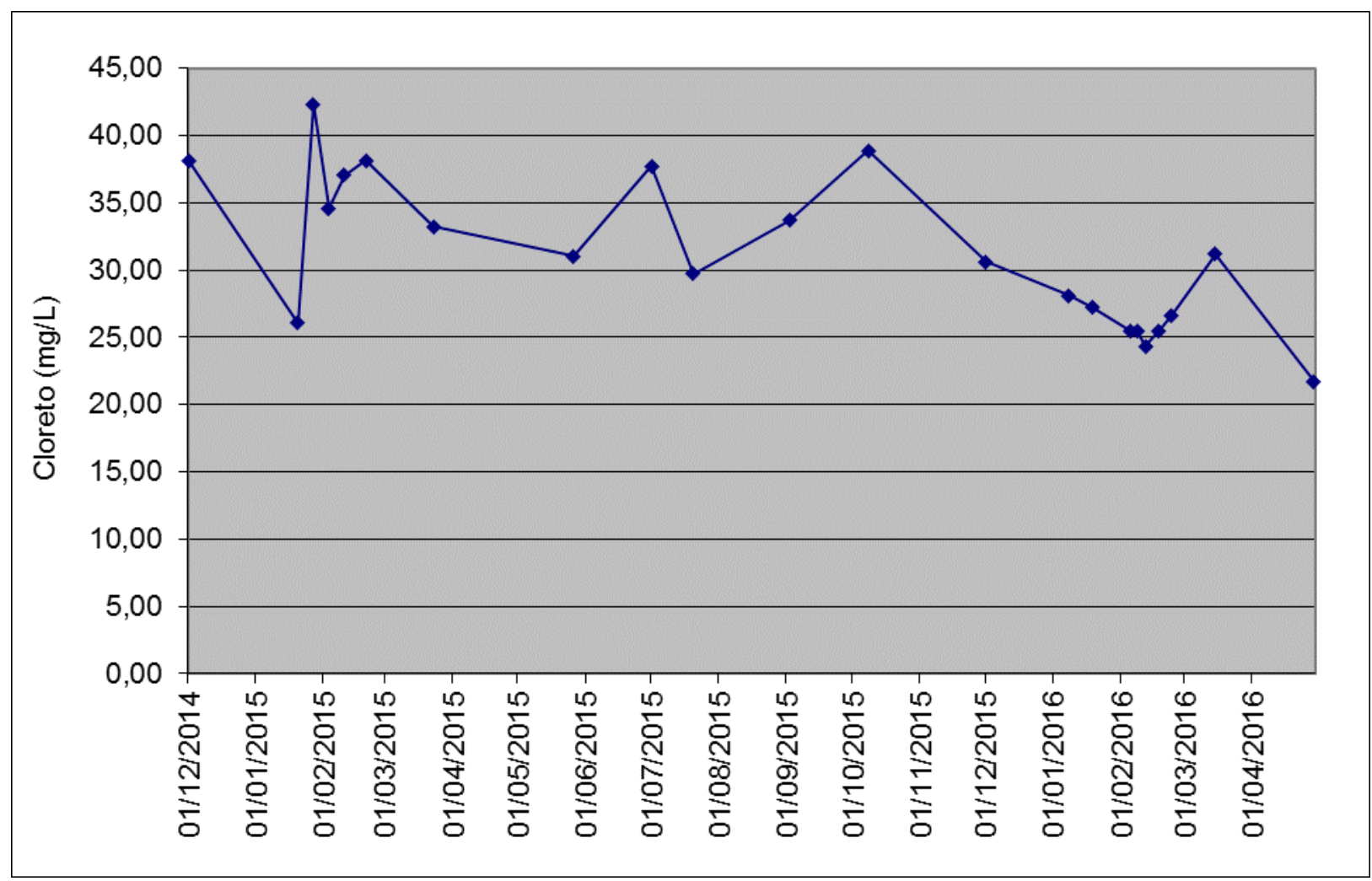

Figura 9 - Conteúdo de cloreto no Piezômetro Moçambique 2.

\subsubsection{Condutividade Elétrica (CE)}

A análise de condutividade indica o teor de sólidos iônicos dissolvidos na água. Não sendo definido na legislação do Brasil um limite superior como aceitável. Porém, deve-se notar que um aumento na condutividade elétrica pode indicar um aumento na quantidade de sais, portanto sinalizando um avanço da cunha salina em direção ao interior do continente pelo excesso de bombeamento nos poços.

Nas Figuras 10, 11, 12, 13 e 14 são mostrados os valores de CE encontrados nos piezômetros e respectivos períodos amostrados. 


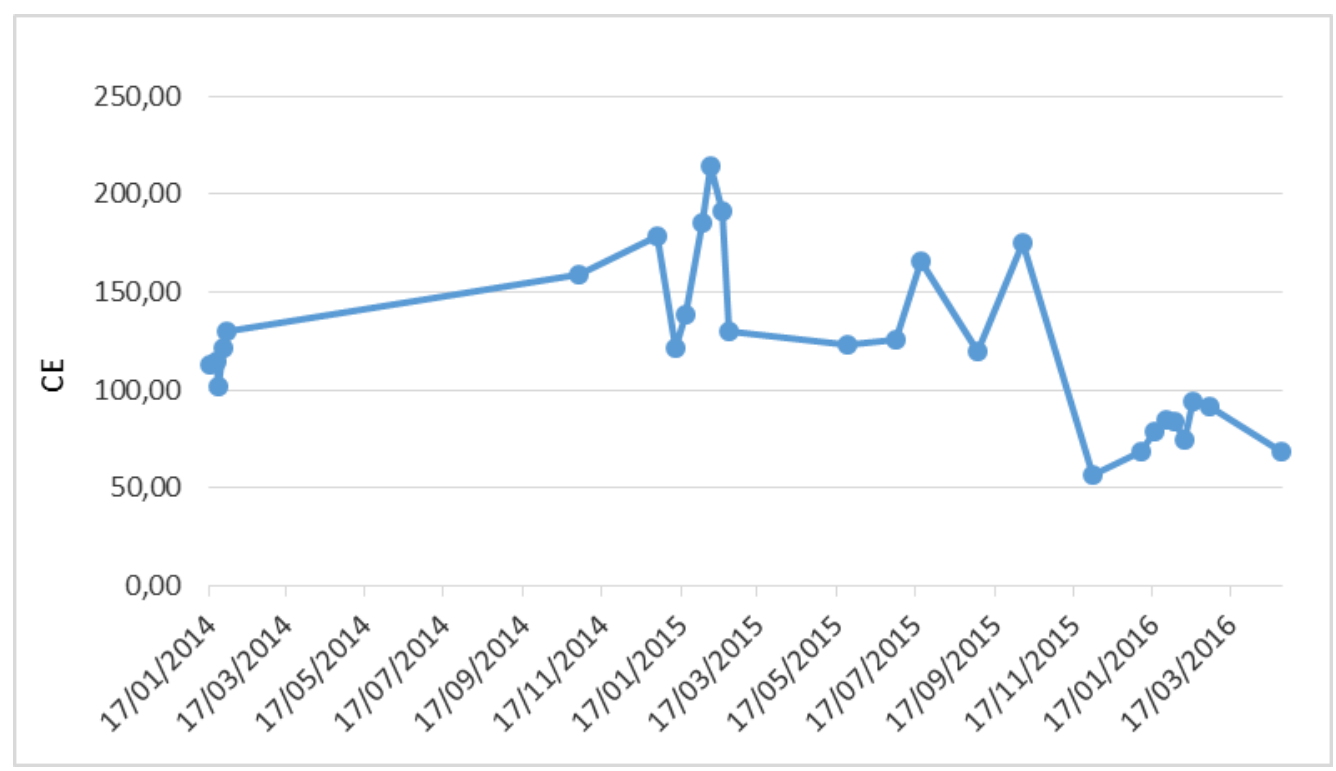

Figura 10 - Valores da condutividade elétrica (CE) em $\mu$ S/cm no Piezômetro Posto Policial.

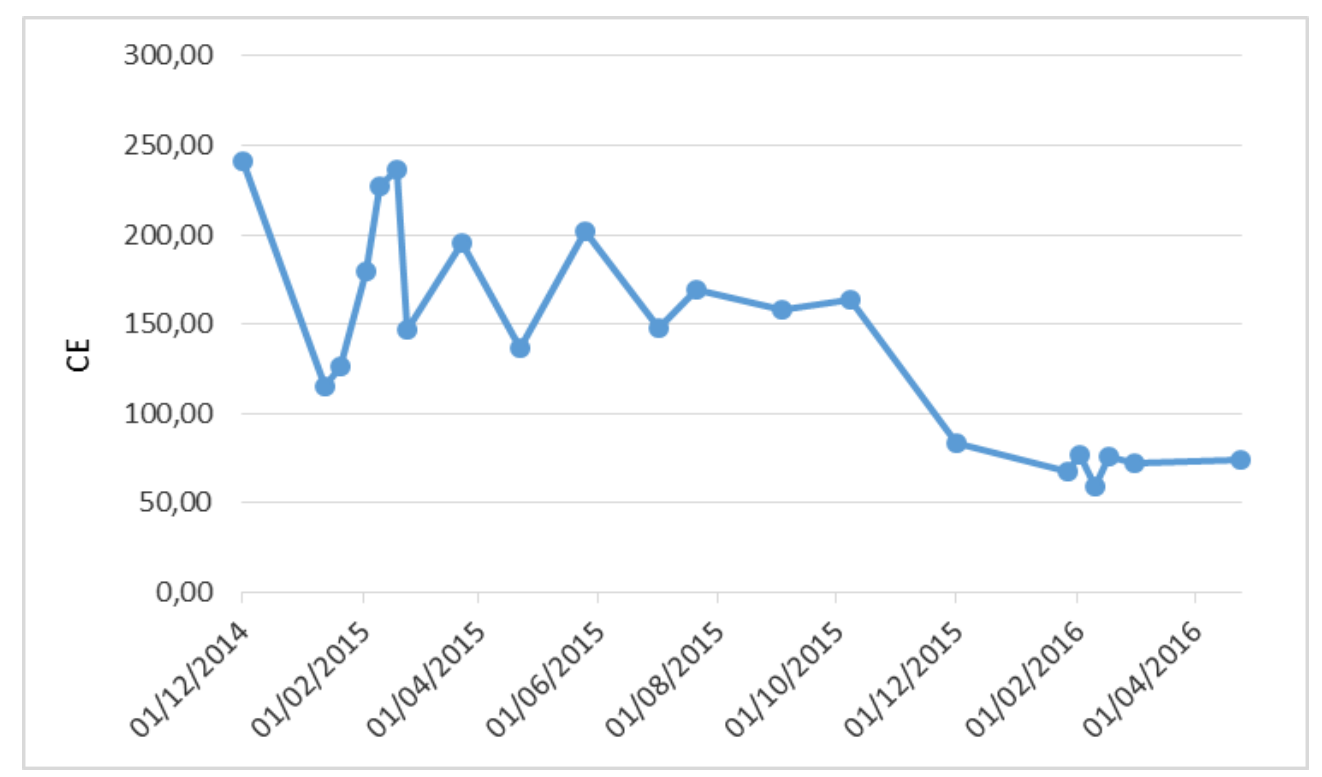

Figura 11 - Valores da condutividade elétrica (CE) em $\mu$ S/cm no Piezômetro Santinho I. 


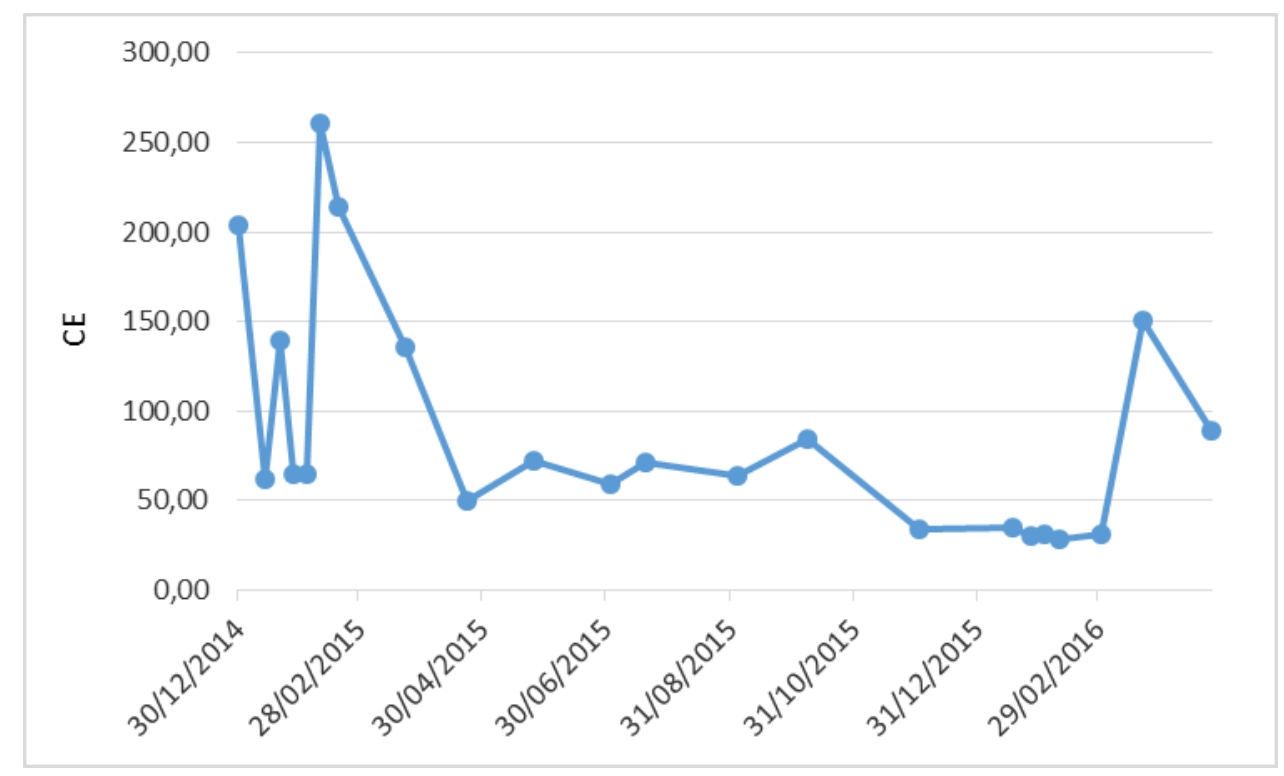

Figura 12 - Valores da condutividade elétrica (CE) em $\mu$ S/cm no Piezômetro Santinho II.

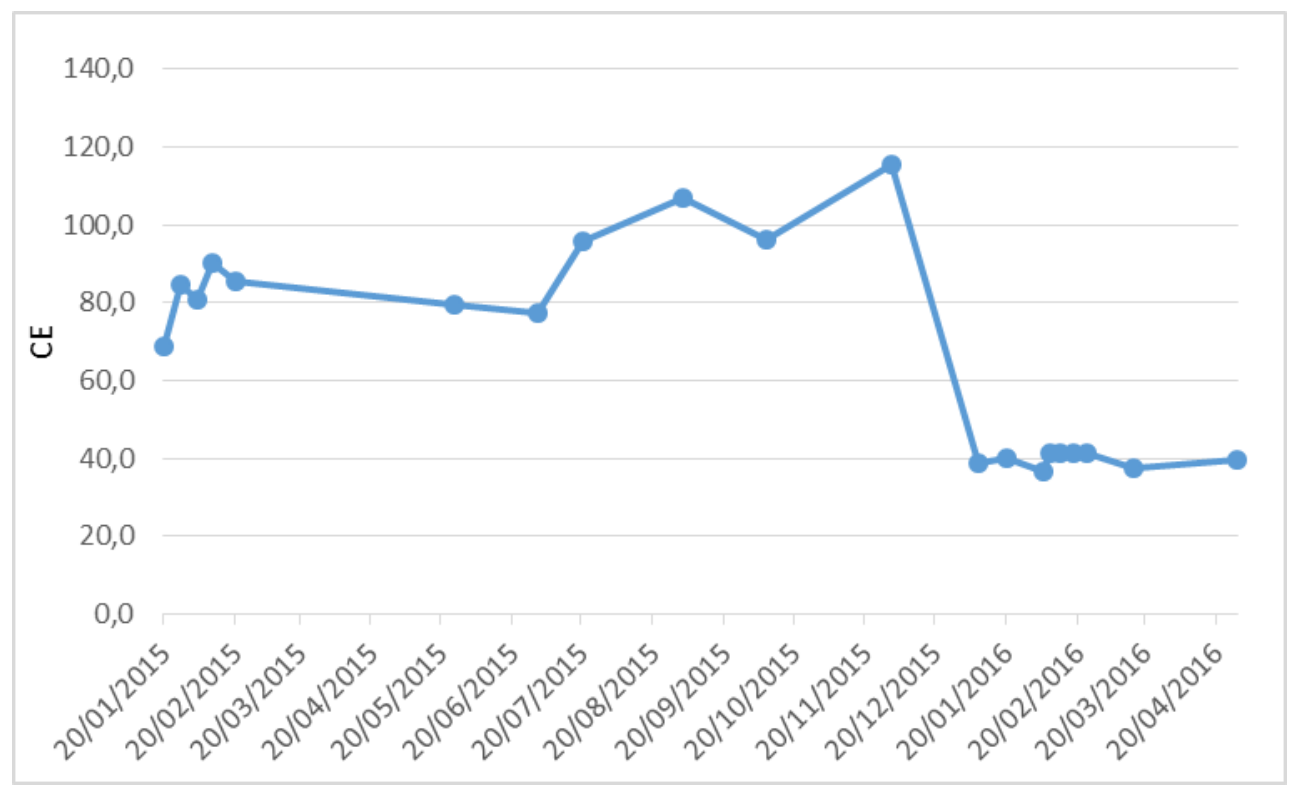

Figura 13 - Valores da condutividade elétrica (CE) em $\mu$ S/cm no Piezômetro Moçambique I. 


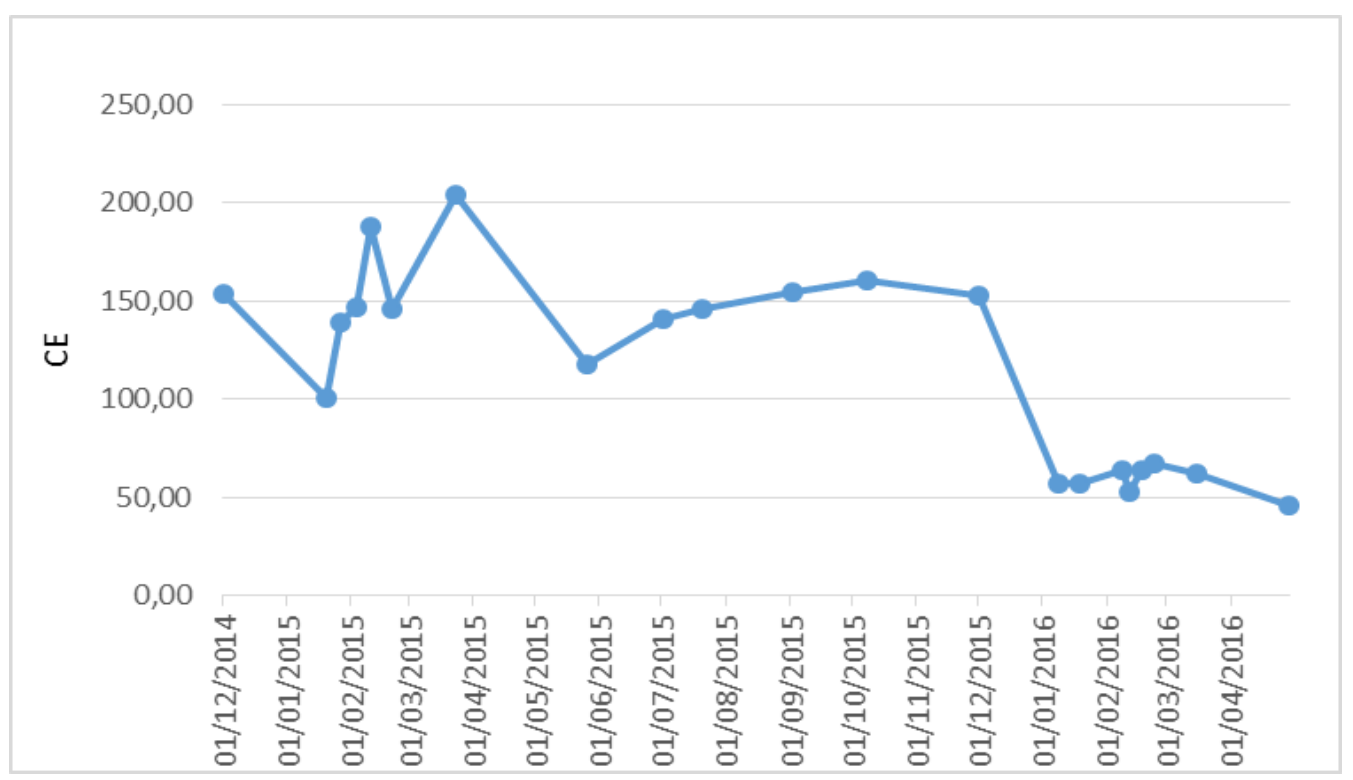

Figura 14 - Valores da condutividade elétrica (CE) em $\mu$ S/cm no Piezômetro Moçambique II.

\subsection{Estudos Geofísicos}

O presente estudo foi executado através de Sondagem Geofísica Elétrica - Método da Eletrorresistividade com a finalidade principal de avaliar hidro geologicamente o Aquífero Costeiro que compreende a Praia dos Ingleses, Rio Vermelho, Praia do Santinho e Praia do Moçambique, em Florianópolis, SC. O estudo foi solicitado pela CASAN - Companhia Catarinense de Águas e Saneamento e justificado pela importância e relevância que as águas subterrâneas têm no abastecimento público da região. Através do estudo de geofísica foi possível diagnosticar espacialmente a área estudada identificando a intrusão e o comportamento da cunha salina. 


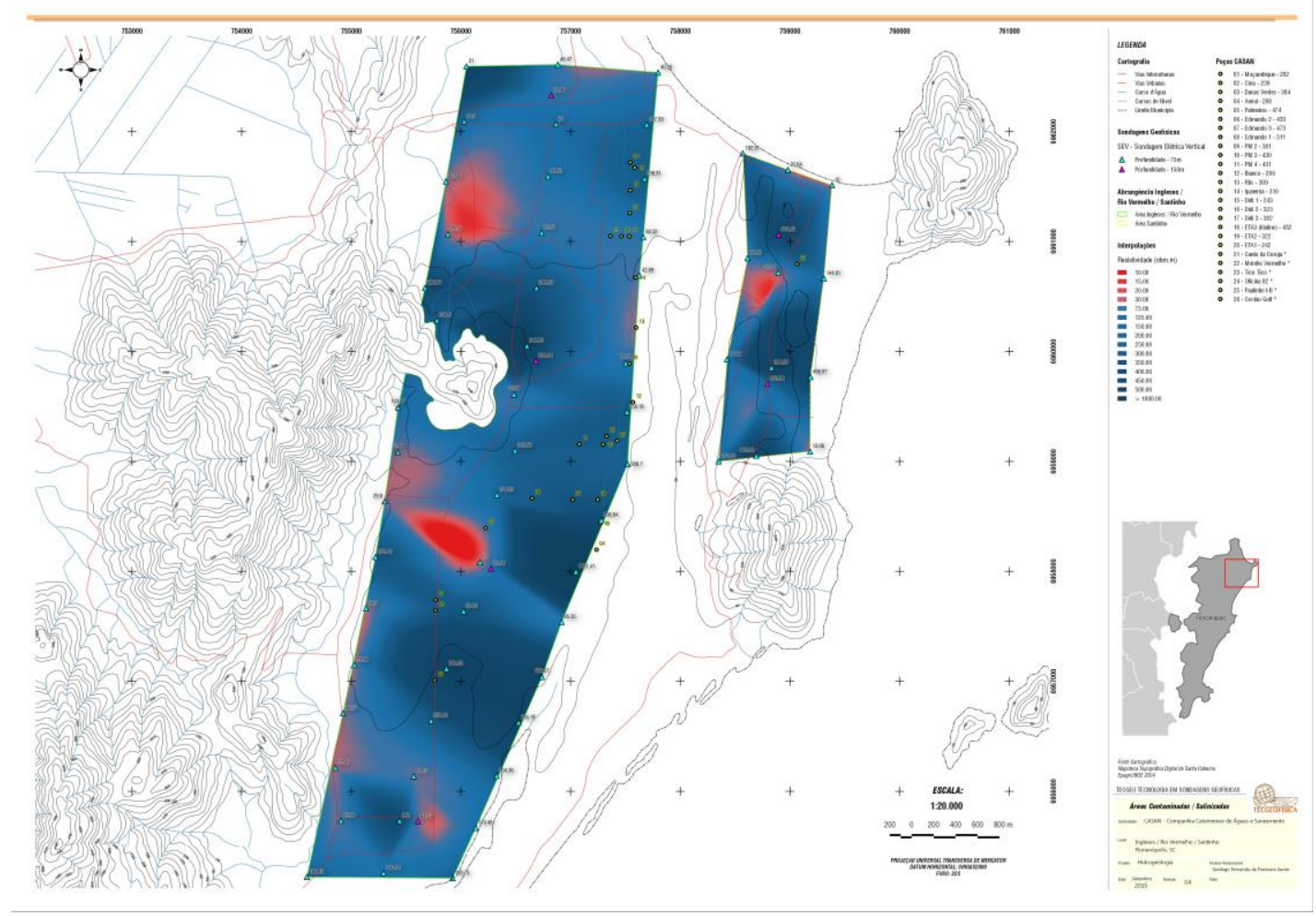

Figura 15 - A imagem mostra os possíveis focos de contaminação (manchas vermelhas) no Aquifero Ingleses englobando os bairros Ingleses, Rio Vermelho e Santinho.

Para o aquífero nas Praias dos Ingleses e região do Rio Vermelho (área mais ao sul) a resistividade apresentou valores entre 200 e $500 \mathrm{ohm} . \mathrm{m}$, isto corresponde a um teor de sais médio de $0,036 \mathrm{~g} / \mathrm{L}$, com base nas correlações entre resistividade e grau de salinização da Tese de Doutorado de Gallas (2000). Na Praia do Santinho o valor da resistividade se apresentou entre 100 e 400 ohm.m correspondendo a um teor de sais médio de 0,057g/L. Considerando o teor de 0,2g/L como balizador (teores menores - água doce; teores maiores - água salobra até água salgada) os teores encontrados indicam águas eminentemente doces, sem presença significativa de sais dissolvidos.

\section{6 - CONSIDERAÇÕES FINAIS}

Com base nos resultados das análises dos 5 piezômetros amostrados foi possível verificar que o do Posto Policial houve um pequeno aumento do conteúdo de cloretos na temporada de verão alcançando teores de $57 \mathrm{mg} / \mathrm{L}$ em fevereiro de 2016. No Piezômetro Santinho I o cloreto alcançou um valor máximo de $55 \mathrm{mg} / \mathrm{L}$ em março de 2016, final do verão. E o Piezômetro Santinho II terminou a temporada com teores de $25 \mathrm{mg} / \mathrm{L}$. O Pz 1 do Moçambique variou muito pouco alcançando teores máximos de cloreto $35 \mathrm{mg} / \mathrm{L}$ em fevereiro de 2015. Já o Pz 2 do Moçambique alcançou no máximo de $42 \mathrm{mg} / \mathrm{L}$ em janeiro de 2015. Os índices de cloreto podem ser considerados 
bem abaixo do limite máximo exigido pela Portaria do Ministério da Saúde 2914/2011 para consumo humano que é de $250 \mathrm{mg} / \mathrm{L}$. Analisando os resultados da condutividade elétrica pode-se dizer que os valores são extremamente baixos não havendo contaminação através da cunha salina.

Considerando os estudos geofísicos realizados, os valores encontrados indicam águas eminentemente doces, sem presença significativa de sais dissolvidos, corroborando com os resultados físico-químicos realizados nos poços e piezômetros.

A CASAN, em 2016 iniciou novos estudos para avaliação do aquífero, incluindo a Modelagem Matemática.

\section{7 - REFERÊNCIAS BIBLIOGRÁFICAS}

APHA. Standard Methods for the Examination of Water and Wastewater. 19a. edição. Eaton, A D., Clesceri, L. S. \& Greenberg A E. Washington, 1995.

Estudo Geofísico, Avaliação da Salinidade dos Aquífero dos Ingleses, 2015. (Estudo Interno CASAN-TECGEOFÍSICA).

GALLAS, J.D.F. 2000. Principais Métodos Geoelétricos e suas Aplicações em Prospecção Mineral, Hidrogeologia, Geologia de Engenharia e Geologia Ambiental. Tese de Doutorado, Rio Claro, UNESP - SP, 174p.

PORTARIA N 2914 DE 29/12/2011 Ministério da Saúde. Dispõe sobre os procedimentos de controle e de vigilância da qualidade da água para consumo humano e seu padrão de potabilidade. 